\author{
Edyta Wolter \\ Zakład Pedagogiki i Psychologii \\ Katedra Nauk Humanistycznych \\ Szkoła Główna Gospodarstwa Wiejskiego w Warszawie
}

\title{
Wychowanie do ochrony przyrody w twórczości Drugiej Rzeczypospolitej
}

\begin{abstract}
Edyta Wolter, Education for Protection of the Environment in the Literary Output from the Period of the Second Republic of Poland

In the Second Republic of Poland, the education for the protection of nature was a part of an implicit didactic and educational process realized in primary and secondary schools - first of all as part of the education in natural science and geography (tourism). The kind of educational climate was created, connected with the establishment of protective care and sensibility for the natural environment, especially the indigenous nature. The article presents the analysis and interpretation of the printed sources, among others the publications by Maximilian Heilpern, Konrad Chmielewski, Hipolita Selmowiczówna-Gnoińska and Maria Lipska-Librachowa as well as Bronisław Gustawicz, Mieczysław Brzeziński, which were used in the didactic and educational practice in the period of the Second Republic of Poland in the process of shaping ecological attitudes. Many of them originated still in the years of Poland's enslavement. They form valuable historical sources for studying, explaining and understanding the ecological education in the interwar period (1918-1939) - as an antecedence of the newest development trends in the educational theory and practice on ecology.
\end{abstract}

Keywords: Second Republic of Poland, ecological education, education for the protection of nature, formation of ecological attitudes, more than material value of nature.

\section{Wprowadzenie}

Celem artykułu jest zaprezentowanie analizy oraz interpretacji źródeł drukowanych, jakie stanowią publikacje: Maksymiliana Heilperna, Konrada Chmielewskiego, Hipolity Selmowiczówny Gnoińskiej i Marii Lipskiej Librachowej oraz Bronisława Gustawicza, Mieczysława Brzezińskiego, które były stosowane w praktyce dydaktyczno-wychowawczej w okresie Drugiej Rzeczypospolitej w kształtowaniu postaw ekologicznych. Wiele z nich powstało jeszcze w latach niewoli narodowej. Stanowią cenne źródła historyczne 
do badania, wyjaśniania i rozumienia edukacji ekologicznej w dwudziestoleciu międzywojennym - jako antecedencji najnowszych kierunków rozwoju teorii i praktyki edukacyjnej w tym zakresie.

Trzeba w tym miejscu podkreślić, że Ministerstwo Wyznań Religijnych i Oświecenia Publicznego podjęło wiele cennych działań na rzecz ochrony przyrody. Przykład stanowi zarządzenie z 1919 r. zakazujące niszczenia, uszkadzania lub wywożenia z kraju zabytków przyrody, takich jak: okazy geologiczne (meteoryty), rośliny (m.in. cis, modrzew polski, limba, wybrane okazy jodły i sosny oraz buk, topola, jesion pospolity, klon, kasztan, lipa, jałowiec, fiołek alpejski i szarotka w Tatrach), zwierzęta (m.in. bocian czarny, łoś, bóbr, kozica, świstak, żubr). W zarządzeniu zapisano, że wykaz zabytków przyrody wymagających ochrony będzie systematycznie uzupełniany ${ }^{1}$. Inny przykład stanowi podpisane 24 września 1919 r. przez Ministra Wyznań Religijnych i Oświecenia Publicznego - Jana Łukasiewicza rozporządzenie w sprawie utworzenia Narodowego Muzeum Przyrodniczego w Warszawie, w celu (m.in.) szerzenia wiedzy przyrodniczej oraz udostępniania zbiorów młodzieży szkolnej². Egzemplifikację stanowi także rozporządzenie Ministra WRiOP w sprawie egzaminów państwowych na nauczycieli szkół średnich z 1920 r., w którym wśród przedmiotów dodatkowych umieszczono najważniejsze wiadomości z zakresu ekologii roślin i zwierząt ${ }^{3}$. Ze względu na cel, w niniejszym artykule ograniczono się jedynie do zasygnalizowania cennej działalności Ministerstwa Wyznań Religijnych i Oświecenia Publicznego na polu ochrony przyrody oraz w zakresie kształcenia i wychowania do ochrony przyrody w Drugiej Rzeczypospolitej.

\section{Popularyzacja nauk przyrodniczych w twórczości dydaktyczno-wychowawczej Maksymiliana Heilperna}

Maksymilian Heilpern, będąc jeszcze uczniem w gimnazjum, przetłumaczył na język polski książkę znanego angielskiego chemika i fizyka - Michaela Faradaya pt. Dzieje świecy. Podczas pobytu na zesłaniu (1881-1884) prowadził badania nad syberyjską florą, a w 1887 r. ukończył studia przyrodnicze. W okresie Drugiej Rzeczypospolitej Ministerstwo Wyznań Religijnych i Oświecenia Publicznego prace nad programem biologii w szkołach powszechnych i średnich powierzyło m.in. Heilpernowi, który także popula-

\footnotetext{
${ }^{1}$ Rozporządzenie Ministerstwa W R i O P o ochronie niektórych zabytków przyrody z 4 września 1919 r. Nr 8340/IV/19, Dziennik Urzędowy Ministerstwa Wyznań Religijnych i Oświecenia Publicznego Rzeczypospolitej Polskiej, Warszawa 1919, Rok II, Nr 10/11, z 1 listopada 1919 r., poz. 3, s. 318-320. Por. „Monitor Polski” Nr 208, z 16 września 1919 r. Por. także „Gazeta Lwowska” nr 219, z 28 września 1919 r.

2 Rozporządzenie Ministra Wyznań Religijnych i Oświecenia Publicznego w sprawie utworzenia Narodowego Muzeum Przyrodniczego w Warszawie, Nr 8676 - IV/19, Dziennik Urzędowy Ministerstwa Wyznań Religijnych i Oświecenia Publicznego Rzeczypospolitej Polskiej, Warszawa 1919, Rok II, nr 10/11, z 1 listopada 1919 r., poz. 6, s. 321-322.

${ }^{3}$ Rozporządzenie Ministra Wyznań Religijnych i Oświecenia Publicznego w sprawie egzaminów państwowych na nauczycieli szkół średnich, z 1 listopada 1920 r. Nr 8378 - IV/20, Dziennik Urzędowy Ministerstwa Wyznań Religijnych i Oświecenia Publicznego Rzeczypospolitej Polskiej, Warszawa 1920, Rok IV, Nr 2, z 16 lutego 1921 r., poz. 16, s. 48-51.
} 
ryzował nauki przyrodnicze ${ }^{4}$. Heilpern wyjaśnił, że wiedzę o wszechświecie, o stosunku zachodzacych $w$ nim zjawisk, czyli o prawach przyrody, nazywamy naukami przyrodni$c z e m i^{5}$. Rozważając problematykę związaną ze sposobem poznawania otaczającej rzeczywistości uogólnił: nauka opiera się [...] przede wszystkim na dokładnym postrzeganiu faktów, które stanowia materiał naukowy i na wyprowadzaniu z nich wniosków [...]. A im bardziej będziemy wszędzie $i$ zawsze prawdę na wierzch wydobywać, tym normalniej, zdrowiej i szczęśliwiej kształtować się będzie życie ludzkości. Dążmy wszędzie i zawsze przede wszystkim do prawdy.

Książki napisane przez Heilperna służyły jako środek dydaktyczny w praktyce edukacyjnej w Drugiej Rzeczypospolitej ${ }^{7}$, zwłaszcza podręcznik dla uczniów szkół elementarnych z zakresu początkowej nauki o przyrodzie. Heilpern twierdził, że proces kształcenia nie może ograniczać się jedynie do przekazywania dzieciom ,gotowych wiadomości” oraz zadawania pracy domowej, lecz ma bazować na obcowaniu z przyrodą, nauczeniu dzieci samodzielnego spostrzegania zjawisk naturalnych w sadzie, ogrodzie, lesie, wodzie (staw), polu i na łące ${ }^{8}$. Opracował książkę poświęconą zasadom botaniki według następujących kategorii: wygląd zewnętrzny roślin, ich budowa wewnętrzna, nauka o czynnościach życiowych, fizjologia roślin, botanika szczegółowa (klasyfikacja i systematyka) ${ }^{9}$. Jest także autorem pogadanek przyrodniczych, w których określił cel nauk przyrodniczych - badanie środowiska życia, np. wody jako siły przekształcającej powierzchnię Ziemi, ale, co podkreślił nie należy zapominać o zwróceniu uwagi uczniów na korzyści, jakie mamy z pracy zwierząt oraz oczyszczania powietrza przez rośliny ${ }^{10}$.

Maksymilian Heilpern dostrzegł wartość wychowania moralnego w procesie kształtowania postaw ekologicznych, ponieważ przyszłość świata nie od nas zależy, lecz przyszłość ludzkości w ludzkich jest tylko rękach [...] Ale rzecz dziwna, w dziejach ludzkości rzadko spotykamy umysty skierowane do polepszenia jej bytu [...] Spoleczeństwo ludzkie jest dotychczas jeszcze zbiorem jednostek, zajętych tylko dązeniem do zaspokojenia swoich potrzeb $i$ zachcianek ${ }^{11}$. Dlatego nauczyciel przyrody powinien być mądrym wycho-

4 J. Miąso, Maksymilian Heilpern (1856-1925), „Oświata Dorosłych” 1961, nr 2, s. 120-121.

5 M. Heilpern, Co to sa nauki przyrodnicze?, Petersburg 1907, s. 14.

${ }^{6}$ M. Heilpern, Jakim sposobem poznajemy otaczajacy świat, Petersburg 1908, s. 16.

7 Przede wszystkim Zasady metodyki ogólnej nauk przyrodniczych, Pogadanki o tajemnicach przyrody, w: Poradnik dla nauczycieli szkół powszechnych. Szczegółowy rozkład materiału naukowego (Nauczycielskie Konferencje Rejonowe Powiatu Włocławskiego), Włocławek 1925, s. 140, 171, 188. Por. Załącznik do Okólnika Nr 13121/1: Wykaz książek poleconych do użytku uczestników kursów wakacyjnych dla nauczycieli szkół powszechnych, Dziennik Urzędowy Ministerstwa Wyznań Religijnych i Oświecenia Publicznego Rzeczypospolitej Polskiej, Warszawa 1921, Rok IV, Nr 9 z 10 lipca 1921, poz. 95, s. 230 i 232.

${ }^{8}$ M. Heilpern, Początki nauki o przyrodzie (podręcznik dla szkół elementarnych ze 137 rysunkami $w$ tekście), Warszawa 1917, s. 5, 29, 70, 89, 96, $102-103$.

9 M. Heilpern, Zasady botaniki podtug 25-go wydania „,Księgi Przyrody” Schoedlera-Thome'go. Wydanie piąte polskie z 281 rysunkami w tekście, Warszawa - Kraków - Lublin - Łódź - Poznań - Wilno - Zakopane 1922, s. 12, 64, 101, 159.

${ }^{10}$ M. Heilpern, Pogadanki o tajemnicach przyrody. Część pierwsza: Wiadomości wstępne o świecie. Wydanie piąte z 75 rysunkami w tekście, Warszawa 1917, s. 239.

${ }_{11}$ M. Heilpern, O Ziemi, Słońcu, Księżycu, gwiazdach i innych ciałach niebieskich czyli o budowie świata, jego początku i końcu. Wykład popularny zasad kosmografii i kosmogonii dla samouków ze 100-ma rysunkami 
wawcą (pedagogiem), który kocha dzieci i wspomaga ich zdolności oraz zamiłowania. W koncepcji Maksymiliana Heilperna nauczyciele powinni się systematycznie kształcić (edukacja ustawiczna), aby jak najlepiej poznać środowisko życia oraz współdziałanie organizmów w zbiorowiskach (ekosystemach ${ }^{12}$ ), takich jak: staw, morze, łąka, las, ogród. Pożyteczne także dla procesu dydaktyczno-wychowawczego jest nawiązanie współpracy np. z ogrodnikiem lub włościaninem podmiejskim [...] suchy wykład nie może zbliżyć do przyrody ani nauczyć ja kochaćl ${ }^{13}$. Jego zdaniem trzeba także umożliwić dziecku samodzielną eksplorację - doświadczanie i poznawanie funkcji życiowych poszczególnych roślin, inspirować zainteresowanie przyrodniczymi ciekawostkami (np. ślimaki odróżniają barwy i lubią żółty kolor).

Heilpern był zwolennikiem wycieczek za miasto, dzięki którym dzieci i młodzież mogą dobrze poznać przyrodę łąk, pól, ogrodów, lasów, gór i grot oraz jezior i stawów. Zwłaszcza, że podczas wycieczek umysł dziecięcy i jego zmysły działają sprawniej, a wiedza zdobyta $\mathrm{w}$ naturalnych warunkach jest szybciej i łatwiej przyswajana niż podczas lekcji w sali szkolnej. Heilpern podkreślił, że żadna roślina i żadne zwierzę - przyniesione do klasy nie zastąpią bezpośredniego zetknięcia się z naturą, zwłaszcza niezmienioną przez człowieka. Bezpośredni kontakt z naturą umożliwia pokazanie stosunków zachodzących w przyrodzie martwej i ożywionej, zrozumienie miejsca organizmów w systemie przyrody i ich wzajemnych zależności (natury żywej), także od warunków ich otoczenia, czynników fizycznych i meteorologicznych. Ponieważ natura jest jednościa $w$ wielości, złączeniem różnorodności, zjednoczeniem rzeczy $i$ sił $w$ jedna żywa catość ${ }^{14}$, każdą wycieczkę trzeba dobrze zaplanować, zachęcając (także) do samodzielnego poznawania roślin i zwierząt, ich cech oraz warunków życia w systemie przyrody. Nauczyciel, przygotowując się do wycieczki, powinien pamiętać o środkach dydaktycznych, niezbędnych podczas eksploracji przyrodniczych (busola, lupa, peseta, małe kartki papieru itp.) i zwrócić uwagę dzieci na: przelatujące ptaki, żabi skrzek, kijanki, nadwodne i podwodne owady i rośliny oraz raczki, pająki, ślimaki - na całokształt flory i fauny danego ekosystemu wraz z nakreśleniem planu miejscowości, granic lasu, łąki, pola, stawu, przepływającej rzeki.

Maksymilian Heilpern we wskazówkach metodycznych dla nauczycieli przedmiotów przyrodniczych uwzględnił więc edukacyjne zadanie kształtowania postaw ekologicznych - nie tylko w zakresie wiedzy przyrodniczej o wzajemnej zależności między organizmami i ich związkami ze środowiskiem życia, ale - co bardzo ważne, także moral-

\footnotetext{
i portretami, wydanie piąte dopełnione i zmienione. Książka polecona przez Ministerstwo WRiOP do egzaminów na nauczycieli wykwalifikowanych, Warszawa - Lublin - Łódź - Poznań - Kraków 1921, s. 199.

${ }_{12}$ Ekosystem (gr. oikos) - mieszkanie, dom, otoczenie, gospodarstwo, środowisko - naturalna jednostka składająca się z elementów żywych i martwych, w której w wyniku wzajemnego oddziaływania elementów powstaje ustabilizowany układ, w którym odbywa się krążenie materii pomiędzy żywymi (biotycznymi) i nieożywionymi (abiotycznymi) składnikami ekosystemu. Ekosystemy mogą być duże (np. ocean) i małe (akwarium), co trzeba podkreślić tworzą je jedynie trwałe układy, o zamkniętym cyklu krążenia. Por. E. Mazur, Stownik ekologii i ochrony środowiska, Szczecin 1995, s. 50.

${ }^{13}$ E. Mazur, Zasady metodyki ogólnej nauk przyrodniczych, wydanie drugie dopełnione, Warszawa 1919, s. 54 .

${ }^{14}$ Ibidem, s. 57.
} 
nych (etycznych), dotyczących przestrzegania norm i zasad postępowania, a więc zakazu niszczenia roślin, bezmyślnego zabijania i więzienia istot żywych w systemie przyrody oraz deptania zasiewów, niszczenia parków i wszelkich dóbr przyrody. Wyjaśnił, że realizując proces dydaktyczno-wychowawczy nie należy bezcelowo zakładać zielniki, zbiory owadów i minerałów, lecz wykorzystywać atlasy przyrodnicze (również atlasiki podręczne ${ }^{15}$ ), tablice okazów naturalnych oraz organizować wycieczki do muzeów przyrodniczych ${ }^{16}$, ogrodów botanicznych i zoologicznych, na wystawy publiczne, odczyty i pogadanki przyrodnicze.

Heilpern podkreślił, że chociaż wycieczki są realizowane przede wszystkim ze względu na cele dydaktyczne - związane z poznaniem środowiska przyrody, trzeba również zwrócić uwagę uczniów na ważne fakty z zakresu geografii, historii, sztuki oraz realizować wychowanie estetyczne na łonie natury, w powiązaniu ze środowiskiem życia.

\section{Wychowanie do ochrony przyrody w twórczości dydaktyczno-wychowawczej Konrada Chmielewskiego}

Konrad Chmielewski jest autorem kilku publikacji, które służyły w praktyce edukacyjnej w drugiej Rzeczypospolitej ${ }^{17}$. Zawarł w nich malownicze ekspresje opisów przyrody Tatr oraz cytaty z polskiej poezji, wysławiającej naturalne piękno przyrody ojczystej. Wyraził swój zachwyt dla piękna Puszczy Kampinoskiej ${ }^{18}$, która stanowi naturalne bogactwo przyrody, ponieważ „w lesie są skarby życia, źródła wód i wilgoci”"19, las jest bogactwem kraju. Chmielewski zachęcał do badania „siedliska człowieka”"20, żyjącego w różnych regionach Polski - na Kaszubach i na Mazowszu oraz do badania pozytywnego wpływu przyrody na pracę zwłaszcza twórców, poetów ${ }^{21}$.

Rozważając miejsce człowieka w przyrodzie Chmielewski uogólnił, że w całokształcie kultury polskiej za mało uwagi poświęcono wiedzy o przyrodzie i środowisku życia człowieka, a nawet ,głuszono popędy współżycia i współbiesiadnictwa [...] lekceważono miłość przyrody”22. Jego zdaniem polskich podróżników charakteryzuje „Sopliców choroba, że im prócz ojczyzny nic się nie podoba"23. Wyjaśnił, że wiedzę o przyrodzie

\footnotetext{
15 Takie jak małe atlasiki podręczne pt. „Minerały”, „Atlasik botaniczny”, „Motyle”, „, Owady”, w: ibidem, s. 117.

${ }^{16}$ Np. muzeum przy Polskim Towarzystwie Krajoznawczym, Muzeum Przemysłu i Rolnictwa, gabinet zoologiczny Uniwersytetu Warszawskiego (dostępny dla publiczności), w: ibidem, s. 114.

${ }_{17}$ Poradnik dla nauczycieli szkół powszechnych. Szczegółowy rozkład materiału naukowego (Nauczycielskie Konferencje Rejonowe Powiatu Włocławskiego), Włocławek 1925, s. 140.

${ }^{18}$ K. Chmielewski, Obrazy ziem polskich. Książka przejrzana przez Sekcję Gieograficzna Stowarzyszenia Nauczycielstwa Polskiego, Warszawa 1908, s. 230 i n.

${ }^{19}$ K. Chmielewski, ,,Twoje ziemie...twoje wody...”. Szkice malownicze z kraju, Warszawa 1907, s. 79.

${ }^{20}$ K. Chmielewski, O moim kraju (szkice krajoznawcze), Warszawa - Kraków 1911, s. 45.

${ }^{21}$ Ibidem, s. 75 i n.

${ }^{22}$ K. Chmielewski, Treść i charakter początków przyrodoznawstwa w naszej szkole, Warszawa 1909, s. 809.

${ }^{23}$ Ibidem, s. 810.
} 
trzeba łączyć z całokształtem poszczególnych aspektów działalności człowieka przede wszystkim z twórczością literacką i poezją, ponieważ bezpośredni kontakt z naturą ułatwia zrozumienie barw, linii, muzycznych tonów, sprzyja wychowaniu estetycznemu ${ }^{24}$.

Chmielewski twierdził, że wiedza o przyrodzie ma również znaczenie wychowawcze, ponieważ ukazuje wartość i piękno życia, a ,patriotyzm przyrodniczy jest częstokroć głębszy od humanistycznego"25. Według Chmielewskiego skuteczne poznawanie natury polega na łączeniu treści przyrodniczych i humanistycznych w pogadankach dla dzieci. W procesie wychowania do harmonijnego życia z naturalnymi prawami przyrody - ,przyrodoznawstwo ma obowiązek nie tylko nauczać o przyrodzie, ale i wychowywać przyrodniczo, w zgodzie z otaczającą przyrodą"26, do harmonijnych (ekologicznych) relacji ze środowiskiem życia. Można w tym celu wykorzystywać czytanki, pogadanki oraz kolorowe ilustracje o tematyce przyrodniczej, pamiętając, że dzieci uczą się, bawiąc.

Konrad Chmielewski jest autorem cennych refleksji dla procesu edukacji ekologicznej dzieci. Twierdził, że kształtowanie miłości do przyrody ojczystej powinno być ujmowane w kategorii „czynnika ewolucyjnego ducha"27 i systematycznie rozwijane w taki sam sposób, jak pozytywne uczucia do rodziny, czyli dzięki celowo realizowanym metodom i zasadom wychowawczym. Ponieważ miłość do przyrody ma być szczera i bezinteresowna - proces edukacji trzeba rozpocząć jak najwcześniej, aby dziecko stopniowo dojrzewając emocjonalnie, intelektualnie i społecznie uczyło się szanować przyrodę i rozumiało, że jest cząstka składowa [...] atomem w harmonii piękna, organizmem w kolisku duchowem z tej przyrody poczętem [...] nie jest dziecko w przyrodzie królewiczem z bajki dla którego przyjemności tylko pachna kwiaty i śpiewaja ptaki [...] a współbiesiadnikiem piękna i bogactwa przyrody ${ }^{28}$. Określił więc bardzo ważne wyzwanie edukacyjne - realizowanie kształcenia i wychowania ekologicznego, które ma być wkomponowane w całokształt oddziaływań szkolnych, z uwzględnieniem naprawiania dotychczasowych niedostatków oraz błędów wychowawczych w zakresie nauki o przyrodzie. Chmielewski uogólnił, że dzięki procesowi dydaktyczno-wychowawczemu do ochrony przyrody dziecko powinno rozumieć, że jest - jak to metaforycznie ujął - współtowarzyszem wiosny życia i „ma obowiązek pielęgnowania w sobie twórczej przyjaźni i współobywatelstwa uczciwego"29 , ucząc się zapobiegania (przeciwdziałania) wszelkiej działalności niszczycielskiej w środowisku przyrody.

\footnotetext{
${ }^{24}$ K. Chmielewski, Nauka początków przyrodoznawstwa i jej historya (Biblioteka nauczyciela tom 1), Warszawa 1921, s. 22.

25 Ibidem, s. 21.

${ }^{26}$ Ibidem, s. 41.

${ }^{27}$ K. Chmielewski, Święto dziatwy i wiosny, w: K. Chmielewski, M. Heilpern, Święto wiosny, Warszawa 1910, s. 1.

28 Ibidem, s. 2.

29 Ibidem.
} 


\section{Wychowanie do ochrony przyrody w publikacjach Bronisława Gustawicza}

W Drugiej Rzeczypospolitej, zwłaszcza w pierwszych latach po odzyskaniu niepodległości w praktyce dydaktyczno-wychowawczej wykorzystywano podczas nauki szkolnej w szkołach powszechnych ${ }^{30}$ książki, napisane przez Bronisława Gustawicza (jeszcze w warunkach niewoli narodowej). Są to książki przygotowane na podstawie badań naukowych ,górnego dorzecza Białego i Czarnego Dunajca w obrębie północnych stoków pasma tatrzańskiego"31, wyjaśniające ukształtowanie terenu w Pieninach oraz zawierające malownicze opisy przyrody na podstawie wycieczek w Pieniny ${ }^{32}$.

Gustawicz opublikował Spis ptaków których chwytania, zabijania i przedawania zabrania się ${ }^{33}$. Uwagę poświęcił również wartości ustawodawstwa ochrony przyrody ${ }^{34}$, pisał: trzeba uchronić od zagłady ptactwo pożyteczne, bronić przed niemiłosiernym dręczeniem [...] dożywiać zimą ${ }^{35}$. W swoich publikacjach zawarł cenne informacje o zwierzętach ssących, ptakach, gadach, płazach, rybach ${ }^{36}$, wyjaśnił jak żyją, odżywiają się i jakie mają znaczenie w systemie przyrody. Prosił, aby nie zabijać jeży ${ }^{37}$, rodzice niechaj nie pozwalają swawoli dzieciom, aby niszczyć zwierzęta ${ }^{38}$, ponieważ jeśli [...] albo sami będziemy wytęiali zwierzęta pożyteczne, albo innym pozwolimy to czynić, prędzej czy później doznamy [...] szkód ${ }^{39}$. Gustawicz jest również współautorem opowiadań przyrodniczych, które obfitują malowniczymi opisami przyrody w maju, gdy „cała przyroda tchnęła świeżością wiosenną"40, następnie w pierwszych dniach czerwca ${ }^{41}$, w letni wieczór ${ }^{42}$, podczas wakacji $^{43}$ oraz jesienią ${ }^{44}$. Oprócz wiedzy o roślinach i zwierzętach zawierają kolorowe ryciny - jako cenny środek dydaktyczno-wychowawczy w Drugiej Rzeczypospolitej.

${ }^{30}$ Poradnik dla nauczycieli szkół powszechnych. Szczegółowy rozkład materiału naukowego (Nauczycielskie Konferencje Rejonowe Powiatu Włocławskiego), Włocławek 1925, s. 144. Por. Załącznik do Okólnika Nr 13121/1: Wykaz książek poleconych do użytku uczestników kursów wakacyjnych dla nauczycieli szkół powszechnych, Dziennik Urzędowy Ministerstwa Wyznań Religijnych i Oświecenia Publicznego Rzeczypospolitej Polskiej, Warszawa 1921, Rok IV, Nr 9 z 10 lipca 1921, poz. 95, s 231.

31 B. Gustawicz, O źródliskach obu Dunajców. Szkic oro-hydrograficzny (osobna odbitka z Pamiętnika Towarzystwa Tatrzańskiego T. X.), Kraków 1885, s. 1.

${ }^{32}$ B. Gustawicz, Przyczynek do flory pienińskiej. Pamiętnik Towarzystwa Tatrzańskiego Tom VI, Kraków 1881, s. $1-8$.

33 B. Gustawicz, Opiekujcie się ptaszkami. Wydanie wtóre, Kraków 1887, s 19-20.

34 Ibidem, s. 4, 18.

35 Ibidem, s. 5, 15.

${ }^{36}$ B. Gustawicz, O pożytecznych zwierzętach $w$ rolnictwie, ogrodnictwie i leśnictwie, Lwów 1899, s. 9-109.

37 Ibidem, s. 32.

38 Ibidem, s. 7.

39 Ibidem, s. 5.

${ }^{40}$ B. Gustawicz, E. Wyrobek, Wśród dolin i gór. Przechadzki przyrodnicze ozdobione i objaśnione w tekście 13 tablicami barwnemi i 152 rycinami, Warszawa 1914, s. 1.

41 Ibidem, s. 78.

42 Ibidem, s. 148.

43 Ibidem, s. 192.

44 Ibidem, s. 242. 


\section{Wychowanie do ochrony przyrody w twórczości dydaktyczno-wychowawczej Mieczysława Brzezińskiego}

Mieczysław Brzeziński swoje publikacje, przygotowane jeszcze przed odzyskaniem niepodległości narodowej poświęcił problematyce przyrody, popularyzował wiedzę o całokształcie życia (współżycia) w systemie przyrody. Jego prace były wykorzystywane w praktyce edukacyjnej w Drugiej Rzeczypospolitej ${ }^{45}$, zwłaszcza w celu podkreślenia wartości estetycznej lasów i puszczy na poszczególnych kontynentach globu ziemskiego. Brzeziński wyjaśnił, że są cenne także ze względu na bogactwo roślin i zwierząt oraz pochłanianie i przechowywanie wilgoci - niezbędnej dla rozwoju życia na ziemi. Dlatego trzeba je ochraniać przed „drapieżnością człowieka”46. Młodym czytelnikom wyjaśnił zjawiska przyrody ${ }^{47}$, takie jak zaćmienie Słońca oraz znaczenie wód lądowych: źródeł i rzek, następnie mórz i oceanów, żyjących w nich roślin i zwierząt, a także bagien i torfowisk, dolin i gór ${ }^{48}$ - przede wszystkim w kontekście ich wartości jako naturalnych dóbr w życiu człowieka. Brzeziński w swoich publikacjach zaprezentował rośliny pokarmowe: palmy daktylowe, kokosowe, drzewa bananowe, krzewy ziemniaczane, owoce i jarzyny, przyprawy korzenne, orzechy ${ }^{49}$. Zachęcał dzieci do obserwowania przyrody ${ }^{50}$ podczas wakacyjnych podróży, kiedy można dużo czasu spędzać na lonie natury i zwiedzać „cuda przyrody”.

Brzeziński jest autorem pogadanek przyrodniczych, w przygotowaniu których posiłkował się dziełami znanych autorów zagranicznych - C. Saffray’a i R. Totha, uwzględniając także uwarunkowania procesu kształcenia w Polsce. Zostały napisane w celu stworzenia sytuacji problemowej w poznaniu zjawisk przyrody i zastosowaniu jej naturalnych praw w życiu codziennym, stanowia wtedy niewatpliwie najwdzięczniejszy materiat nauki dla ucznia, jak $i$ dla samego nauczyciela ${ }^{51}$. Brzeziński twierdził, że pogadanki są niezbędne, zwłaszcza na etapie kształcenia elementarnego jako pomoc w zdobywaniu samodzielnych doświadczeń eksploracyjnych przez dzieci. Powinny być realizowane przez osoby, które mają duży zasób wiedzy przyrodniczej, które nie poprzestają na ich odczytaniu, lecz rozmowę z uczniami dopełniają edukacyjnymi wycieczkami w środowisku przyrody. Dzięki łączeniu walorów dydaktycznych pogadanek przyrodniczych z wycieczkami (np.) do folwarku - dzieci mogą bardziej wszechstronnie poznać zwierzęta,

45 Poradnik dla nauczycieli szkół powszechnych. Szczegółowy rozkład materiału naukowego (Nauczycielskie Konferencje Rejonowe Powiatu Włocławskiego), Włocławek 1925, s. 144, 171.

${ }^{46}$ M. Brzeziński, O morzach i lądach. Wydanie trzecie z rysunkami, Warszawa 1907, s. 94.

${ }^{47}$ M. Brzeziński, O zaćmieniach Stońca $i$ Księżyca. Odczyt z obrazami niknącemi, wydanie czwarte z 10-ma rysunkami, Warszawa 1925, s. 27.

${ }^{48}$ M. Brzeziński, O morzach i lądach, wydanie trzecie z rysunkami, Warszawa 1907, s. 130 i n.

${ }_{49}$ M. Brzeziński, Owady i ich znaczenie w gospodarstwie (z 50-ma rysunkami), wydanie trzecie, Warszawa 1906, s. 17, 32, 42, 57, 73, 80, 87, 99.

${ }_{50}$ M. Brzeziński, Moje wakacje na wsi, wydanie nowe, przerobione i powiększone, z licznemi rysunkami, Warszawa 1911, s. 21 i n.

${ }_{51}$ M. Brzeziński, Pogadanki z dziedziny przyrody i przemystu część pierwsza i druga. Pośród zwierząt i roślin, wydanie ósme przejrzane i dopełnione przez Władysława Umińskiego wieloma rysunkami, Warszawa 1925, s. 3. 
takie jak: pies, krowa, koń, osioł, a także zobaczyć ptasie gniazda, poznać znaczenie mrówek, ryb, raków, żab, owadów dla środowiska naturalnego. Dowiadują się, jakie rośliny pokarmowe, warzywa i owoce rosną w ogrodzie i w sadzie oraz które z tych darów przyrody są wykorzystywane w lecznictwie, w przemyśle farmaceutycznym ${ }^{52}$. Zwłaszcza, gdy treść pogadanek uświadamia dzieciom, że z roślin powstaje wiele przedmiotów, m.in. powstaje $\mathrm{z}$ nich papier ${ }^{53} \mathrm{i}$ atrament, a poszczególne gatunki drzew są wykorzystywane w budownictwie.

Brzeziński jest współautorem pogadanek, wśród których walor przyrodniczo-ekologiczny mają następujące: „Gdzie jest koniec ziemi?”, „Na czem opiera się ziemia?”, „O niebie”, „Czy Słońce naprawdę porusza się po niebie?”, „Czy to prawda, że Księżyc jest jasny?”, „O gwiazdach i kometach”, „Jak się o tem wszystkiem ludzie dowiedzieli”, „Dlaczego w roku jest dwanaście miesięcy?”, „Dlaczego Słońce i Księżyc czasem przestają świecić?" 54 . Warto także w tym miejscu podkreślić, że według Brzezińskiego wychowanie jest sztuką, za pomocą przyrodniczej metafory wyraził: nie sztuka pestkę w ziemi zasadzić - sztuka otrzymać z niej kiedyś smaczne, posilne jabłka. [...] Jak żadna roślina nie rozwinie się dobrze bez odpowiedniego pokarmu, wilgoci, światta, ciepła itp. Tak samo dziecko może rozwijać się, rosnać zdrowo tylko przy odpowiednich warunkach otoczenia ${ }^{55}$. Porównał więc proces wychowania dzieci do procesu hodowania roślin, drzew - podkreślając znaczenie ochronnej troski o środowisko życia.

\section{Wychowanie do ochrony przyrody w podręcznikach szkolnych Hipolity Selmowiczówny Gnoińskiej i Marii Lipskiej Librachowej}

Maria Lipska Librachowa w pedagogicznych rozważaniach, poświęconych metodom kształcenia dzieci w szkołach powszechnych nawiązała do koncepcji Nowego Wychowania, m.in. do progresywizmu pedagogicznego Johna Deweya ${ }^{56}$, który był zwolennikiem znanej tezy twórcy pojęcia „ekologia” - Ernsta Haeckela, według której indywidualny rozwój człowieka przypomina rozwój ludzkości. Wraz z Hipolitą Selmowiczówną Gnoińską napisały pogadanki dla dzieci, poświęcone przyrodzie, które Ministerstwo Wyznań Religijnych zatwierdziło do użytku szkolnego ${ }^{57}$. Współautorki wyjaśniły, że w pierwszej

\footnotetext{
52 Przykłady stanowią: olej wytłaczany z orzechów krzaka - rycinusa, odwar rumianku, mięty i siemienia lnianego, krople laurowe.

${ }^{53}$ Zob. opis produkcji papieru, także ze starych szmat, które są zbierane na śmietnikach, w: M. Brzeziński, Pogadanki z dziedziny przyrody i przemystu część pierwsza i druga. Pośród zwierząt $i$ roślin, wydanie ósme przejrzane i dopełnione przez Władysława Umińskiego wieloma rysunkami, Warszawa 1925, s. 245 i n.

${ }_{54}$ Pogadanki o niebie i ziemi przełożył H. Wernic, uzupełnił M. Brzeziński, wydanie szóste objaśnione rysunkami, Warszawa 1917, s. 3, 15, 19, 24, 32, 42, 49, 57, 63.

${ }_{55}$ M. Brzeziński, Jak wychowywać dzieci na zdrowych i silnych ludzi?, Warszawa 1925, s. 3 i 5.

${ }_{56}$ M. Lipska Librachowa, O metodach nauczania $w$ szkole elementarnej. Rozważania metodyczno-pedagogiczne, Warszawa 1918, s. 37, 59, 74.

${ }^{57} \mathrm{~W}$ sprawie wydawnictw i środków naukowych zatwierdzonych do użytku szkolnego, Dziennik Urzędowy Ministerstwa Wyznań Religijnych i Oświecenia Publicznego Rzeczypospolitej Polskiej Rok 1929 Nr ogólnego zbioru 1/208 - 13/220. Rocznik XII, Warszawa 1929, poz. 134, s. 437.
} 
klasie nauki szkolnej problematyka przyrodnicza o drzewach, kwiatach, ptakach i zwierzętach stanowi implikację całokształtu procesu dydaktyczno-wychowawczego. Natomiast pogadanki o tematyce przyrodniczej są: po pierwsze - środkiem ogólnokształcącym, po wtóre - stanowią podstawę przygotowania do dalszej nauki o przyrodzie, zwłaszcza gdy dzieci ,przynoszą do szkoły pewien zasób wiadomości przyrodniczych, zdobytych na drodze osobistych doświadczeń" ${ }^{58}$ w tym zakresie.

Autorki podkreśliły, że rozpisana na pięćdziesiąt cztery jednostki lekcyjne książka nie jest standardowym podręcznikiem do nauki przyrody, lecz „fragmentem całorocznej pracy z dziećmi" "59, z uwzględnieniem systematycznych wycieczek do ogrodu szkolnego (w celu lepszego poznania roślin i obserwacji zmian zachodzących w środowisku przyrody, które są w poszczególnych porach roku) oraz kilku wycieczek do ogrodów miejskich, a także wycieczek na wieś dla dzieci miejskich (jesienią i wiosną) ${ }^{60}$. Zrealizowane obserwacje podczas wycieczek stanowią inspirację dla edukacyjnego doświadczenia w procesie kształcenia szkolnego zarówno dla dzieci, jak i dla nauczycieli. Zwłaszcza gdy podczas wycieczek do ogrodu szkolnego dzieci pytają nauczyciela o nazwy kwiatów i warzyw, poznają gatunki drzew (np. kasztan, klon), rozpoznają liście i owoce drzew (np. klonu) i naklejają je na papierowe pasy ${ }^{61}$. Autorki w swoich publikacjach zaprezentowały także przebieg trzech wycieczek do ogrodów miejskich, które odbyły się w październiku - do Parku Ujazdowskiego, do Ogrodu Saskiego i do Ogrodu Krasińskich w Warszawie. Celem tych wycieczek było potwierdzenie tezy, że jesienne zmiany zachodzą nie tylko w ogródku szkolnym, lecz w całej przyrodzie oraz utrwalenie wiadomości i porównanie ogrodów wraz ze zdobyciem nowych doświadczeń. Ponieważ analizowane wycieczki stanowią implikację cyklu lekcji o przyrodzie, dzieci nauczyły się rozróżniać kilka rodzajów drzew (kasztanowiec, klon, orzech włoski), kwiatów (nasturcja, nagietki, astry), zapoznały się z budową drzew i roślin (pień, gałęzie, liście, korzeń przy pieniu), poznały kształt i zewnętrzną budowę liści, owoce kasztanowca, orzecha włoskiego, klonu. Co cenne, dowiedziały się, że są różne rodzaje ogrodów, m.in. są „,ogrody spacerowe" ${ }^{\prime 62}$. Wycieczki do Ogrodu Krasińskich w Warszawie odbyły się także wiosną ${ }^{63}$.

Ekologiczne pogadanki poświęcono zimie ${ }^{64}$, życiu ptaków ${ }^{65}$ i zwierząt ${ }^{66}$, związane były z obserwacją porównawczą (doraźną) drzew (początkowo swobodną, następnie kie-

\footnotetext{
${ }_{58}$ M. Librachowa i H. Selmowiczówna, Pogadanki z dziećmi. Część pierwsza; Pierwszy rok nauczania (dla szkół miejskich). Książka dla nauczyciela Ministerstwo Wyznań Religijnych i Oświecenia Publicznego Materiały i opracowania z zakresu pedagogiki, Lwów - Warszawa 1922, s. 4.

59 Ibidem, s. 5.

60 Ibidem, s. 29.

${ }^{61}$ Por. Lekcja 2: Pierwsza wycieczka do ogrodu; Lekcja 3: Druga wycieczka do ogrodu; Lekcja 4: Trzecia wycieczka do ogrodu; Lekcja 5: Czwarta wycieczka do ogrodu; Lekcja 6: Piąta wycieczka do ogrodu szkolnego; Lekcje 20-24: Wycieczki do ogrodu szkolnego w listopadzie; Lekcja 41: Opowiadanie dzieci, spacer do ogrodu szkolnego, w: ibidem, s. 34-40, 58-59, 80.

${ }^{62}$ Lekcja 7, 8, 9: Trzy wycieczki do ogrodów miejskich, w: ibidem, s. 41-44.

${ }^{63}$ Lekcja 40: Pierwsza wiosenna wycieczka do ogrodu miejskiego, w: ibidem, s. 79.

${ }^{64}$ Lekcja 27 i 28: Śnieg - zima, w: ibidem, s. 63.

${ }^{65}$ Lekcja 29: $O$ gilu; Lekcja 44: $O$ wronie; Lekcja 49: $O$ gniazdach, w: ibidem, s. 65, 85, 94-95.

${ }^{66}$ Lekcja 33-34: Koń i stajnia; Lekcja 37: O kozie; Lekcja 38 i 39: O króliku, w: ibidem, s. 69-73, 75, 76.
} 
rowaną przez nauczyciela ${ }^{67}$ ) oraz wiosennych kwiatów ${ }^{68}$. Trzeba podkreślić, że Hipolita Gnoińska napisała interesującą książkę o nauczaniu wierszy w klasie pierwszej szkoły powszechnej. Wśród zaprezentowanych utworów poetyckich dla dzieci są wiersze Marii Konopnickiej oraz Teofila Lenartowicza o porach roku, nawiązujące do naturalnych przemian w środowisku życia ${ }^{69}$. Tematyka przyrodnicza została uwzględniona przez Hipolitę Gnoińską w praktyce dydaktyczno-wychowawczej również podczas uroczystości szkolnych, z okazji Święta Niepodległości, podczas której dzieci otrzymały roślinki do hodowania - jako symboliczną pamiątkę (dla każdego dziecka), którą trzeba pielęgnować ${ }^{70}$. Poznały także utwory poetyckie o niepowtarzalnym pięknie przyrody ojczystej ${ }^{71}$.

Hipolita Gnoińska i Maria Librachowa są współautorkami cennych, ze względu na problematykę wychowania do ochrony przyrody podręczników szkolnych. Przykład stanowi ilustrowany podręcznik pt. Moja wieś. Przyroda i geografja dla III klasy wiejskich szkół powszechnych. Zeszyt ucznia, w którym znajdują się tabelki do wypełnienia przez ucznia, poświęcone drzewom (ich nazwom, ubarwieniu liści) ${ }^{72}$, pracom jesiennym w polu i ogrodzie ${ }^{73}$, roślinom w okresie zimy ${ }^{74}$, pogodzie ${ }^{75}$. Na łamach podręcznika autorki zachęcają dzieci do hodowania roślin doniczkowych, obserwowania ptaków ${ }^{76}$ i rozwijających się pąków drzew ${ }^{77}$, dbania o zwierzęta - zwłaszcza zimą, gdy trzeba je dokarmiać ${ }^{78}$, uwrażliwiają dzieci na cierpienie ptaków z powodu głodu ${ }^{79}$. W podręczniku umieszczono również fragmenty ulotek Towarzystwa Opieki nad Zwierzętami. Pierwszy, pt. Co powiedziałby koń woźnicy, gdyby mógt mówić sprzyja wychowaniu ekologicznemu, ponieważ uwrażliwia duszę dziecka na złe traktowanie zwierząt:

Dlaczego mnie bijesz? Cóż zrobiłem? Poślizgnąłem się. Czy to moja wina? Gdybym chodził swobodnie, jak ty, tobym się nie ślizgał.

Jeśli zwalniam kroku, mówisz, że śpię, lub, że jestem leniwy, ale nigdy nie przyjdzie ci na myśl, że jestem okropnie zmęczony. A jednak wiesz, że ci pomagam ze wszystkich moich sił. Spełniam ciężką pracę i beze mnie musiałbyś to wszystko robić sam.

\footnotetext{
${ }^{67}$ Lekcja 30 i 31: Sosna i świerk, w: ibidem, s. 66.

${ }^{68}$ Lekcja 48: Kwiaty wiosenne, w: ibidem, s. 90.

${ }^{69}$ H. Gnoińska, Nauczanie wierszy w klasie I-ej szkoty powszechnej. (Z praktyki szkolnej nr 7), Warszawa 1929, s. $15,35,65$.

${ }^{70} \mathrm{H}$. Gnoińska, Obchody uroczystości i inne fragmenty z życia szkolnego. Czesść 1 (Z praktyki szkolnej nr 20), Warszawa 1934, s. 21-22.

71 Ibidem, s. 28, 33.

${ }^{72}$ H. Gnoińska i M. Librachowa, Moja wieś. Przyroda i geografja dla III klasy wiejskich szkół powszechnych. Zeszyt ucznia (ilustracje: M. Bylina, S. Łuckiewicz, J. Szancer, E. Wiśniewska), Warszawa - Lwów

73 Ibidem, s. 9.

74 Ibidem, s. 10-11.

75 Ibidem, s. 102.

${ }^{76}$ Ibidem, s. 105, 109.

77 Ibidem, s. 112.

78 Ibidem, s. 69.

79 Ibidem, s. 75.
} 1935, s. 8. 
Ale mnie bijesz ciągle: gdy ciężar za wielki, wjazd pod górę za długi, gdy jestem chory lub zmęczony. I śmiesz to czynić, bo nie umiem się skarżyć, bo nie umiem krzyczeć! ${ }^{80}$

Drugi cytat z ulotki Towarzystwa Opieki nad Zwierzętami pt. Co mówi nasz najwierniejszy przyjaciel także służy dydaktyczno-wychowawczą pomocą, w kształtowaniu postaw ekologicznych wobec zwierząt:

Żadne ze zwierząt nie jest tak ciągle z tobą, jak ja.

Towarzyszę ci wszędzie.

Pilnuję twego majątku.

Gdy jesteś samotny, przywiązaniem swem staram się zastąpić przyjaciela.

A więc:

nie odmawiaj mi skromnego posiłku, dwa razy dziennie;

daj legowisko suche i ciepłe;

opiekuj się mną w chorobie;

nie skąp dobrego słowa i pieszczoty, bo wiesz, jaką to mi radość sprawia i jak umiem dziękować;

obchodź się ze mną dobrze, bo ja też odczuwam ból, tęsknotę i krzywdę ${ }^{81}$.

Omawiany podręcznik zwieńczono atlasikiem roślin kwitnących jesienią, wraz z wycinankami liści do pokolorowania i naklejania na kartoniku ${ }^{82}$. Hipolita Gnoińska i Maria Librachowa opracowały podobny podręcznik dla dzieci uczących się w miejskich szkołach powszechnych pt. Moja wieś. Przyroda i geografja dla III klasy miejskich szkót powszechnych. Zeszyt ucznia, który implikuje takie same treści kształcenia w zakresie wiedzy o drzewach ${ }^{83}$, roślinach $^{84}$, ptakach $^{85}$, harmonogramie jesiennych prac w polu i w ogrodzie ${ }^{86}$, dokarmianiu zwierząt zimą ${ }^{87}$. W tym podręczniku są również fragmenty z ulotek Towarzystwa Opieki nad Zwierzętami, służące jako środek dydaktyczny w kształtowaniu postaw ekologicznych dzieci ${ }^{88}$. Umieszczono je także w podręczniku pt. Moje miasto. Przyroda i geografja dla III klasy miejskich szkót powszechnych. Zeszyt ucznia ${ }^{89}$. H. Gnoińska i M. Librachowa wśród treści kształcenia umieściły wskazówki dla dzieci, podpowiadające im, jak postępować z psem podczas podróży, jak go

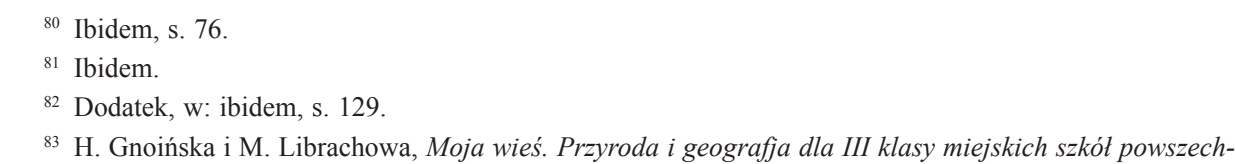
nych. Zeszyt ucznia, wydanie drugie (podręcznik zatwierdzony do użytku w szkołach pismem Ministerstwa WRiOP z dnia 31 lipca 1935 roku Nr II Pr - 13512, ilustracje: B. Bylina, F. Chotomski, S. Łuckiewicz, J. Szancer, E. Wiśniewska), Lwów 1938, s. 8.

${ }^{84}$ Ibidem, s. 10-11.

85 Ibidem, s. 105.

86 Ibidem, s. 9.

87 Ibidem, s. 69.

88 Ibidem, s. 76.

${ }^{89}$ H. Gnoińska, M. Librachowa, Moje miasto. Przyroda i geografja dla III klasy miejskich szkół powszechnych. Zeszyt ucznia (ilustracje: M. Bylina, F. Ciechomski, S. Łuckiewicz, J. Szancer, E. Wiśniewska), Lwów 1936, s. 19. Por. H. Gnoińska i M. Librachowa, Moje miasto. Przyroda i geografja dla III klasy miejskich szkót powszechnych. Zeszyt ucznia (ilustracje: M. Bylina, F. Ciechomski, S. Łuckiewicz, J. Szancer, E. Wiśniewska), Lwów 1938, s. 19 i 28. 
odżywiać - im lepiej obchodzisz się z psem, tem staje się on lepszy, zmyślniejszy ${ }^{90}$. Uwagę poświęciły także wartości pielęgnowania koni ${ }^{91}$ oraz zwierzętom domowym ${ }^{92}$, ptakom $^{93}$, roślinom ozdobnym i drzewom ${ }^{94}$, przyrodzie najbliższej okolicy ${ }^{95}$.

\section{Zakończenie}

W Drugiej Rzeczypospolitej wychowanie do ochrony przyrody stanowiło implikację całokształtu procesu dydaktyczno-wychowawczego, realizowanego w szkołach powszechnych i średnich - przede wszystkim w ramach treści kształcenia z przyrody i geografii (krajoznawstwa). Co cenne, kreowano klimat wychowawczy, związany z kształtowaniem ochronnej troski i wrażliwości dla środowiska przyrody, zwłaszcza przyrody ojczystej. Zaprezentowane, celowo wybrane przykłady dzieł, służyły w procesie wychowania do cenienia ponadmaterialnej wartości przyrody. Wiele z nich powstało jeszcze w warunkach niewoli narodowej. Okazały się bardzo pożyteczne w procesie nauki szkolnej, zwłaszcza w pierwszych latach Drugiej Rzeczypospolitej - po odzyskaniu niepodległości w $1918 \mathrm{r}$.

\footnotetext{
90 Ibidem, s. 26.

91 Ibidem, s. 16-19.

92 Ibidem, s. 31, 39, 63, 66, 68, 70, 77.

93 Ibidem, s. 43, 46-48.

${ }_{94}$ Ibidem, s. 13, 15, 125, 129.

95 Ibidem, s. 138-139.
} 
